\title{
Penegakkan Hukum Peraturan Daerah Nomor 01 Tahun 2014 Tentang Penanganan Gelandangan Dan Pengemis Daerah Istimewa Yogyakarta
}

\author{
Mufti Khakim, Egi Purnomo Ajib
}

Program Studi Ilmu Hukum, Universitas Ahmad Dahlan, Yogyakarta

\section{INFORMASI ARTIKEL \\ Sejarah Artikel: \\ Diterima: 3/2/2021 \\ Disetujui: $2 / 3 / 2021$ \\ Kata kunci: \\ Penegakkan Hukum; \\ Gelandangan; \\ Pengemis \\ Keywords: \\ Law Enforcement;

\begin{abstract}
ABSTRAK
Penelitian ini merupakan penelitian hukum tentang penegakkan hukum Peraturan Daerah Nomor 01 Tahun 2014 Tentang Penanganan Gelandangan dan Pengemis. Fokus penelitian ini pada aspek hukum yang menjadi bagian dari solusi penanganan gelandangan dan pengemis di Yogyakarta pasca diberlakukan Peraturan Daerah Nomor 01 Tahun 2014. Metode yang digunakan dalam penelitian ini adalah dengan menggunakan tiga pendekatan yaitu pendekatan yuridis sosiologis, pendekatan kebijakan dan pendekatan nilai. Analisis yang digunakan adalah analisis kualitatif dengan kesimpulan diambil secara deduktif. Hasil dari penelitian ini menunjukkan bahwa penanganan gelandangan dan pengemis dari aspek hukum pidana di Yogyakarta pasca diberlakukan Peraturan Daerah Nomor 01 Tahun 2014 telah dilaksanakan sebagi bagian dari kebijakan secara lebih luas, integralistik, dan terpadu.
\end{abstract}

Vagrant;

Beggar

\section{ABSTRACT}

This research is a legal research on law enforcement of Regional Regulation Number 01 of 2014 concerning Handling of Homeless and Beggars. Researching about how law enforcement for the handling of homeless people and beggars in Yogyakarta after the enactment of Regional Regulation Number 01 of 2014. The problem is how law enforcement of Regional Regulation Number 01 of 2014 concerning Handling Homeless and Beggars in Yogyakarta The method used in this study is to use three approaches, namely sociological juridical approach, policy approach and value approach. The analysis used is qualitative analysis with conclusions drawn deductively. The issue of handling homeless people and beggars from a criminal aspect is part of a broader policy. Handling is carried out in an integralistic and integrated manner. This research will focus on the legal aspects that are part of the solution to dealing with homeless people and beggars.

\section{Pendahuluan}

Wilayah perkotaan menyimpan persoalan sosial yang kompleks, salah satunya adalah persoalan gelandangan dan pengemis. Banyak orang yang mengadu nasib ke kota atau biasa disebut dengan kaum urban, mereka datang ke kota dengan harapan akan mendapatkan pekerjaan dan gaji yang cukup. Mimpi mendapatkan penghidupan yang lebih baik dari pada hidup di desa menjadi modal pergi ke kota tanpa keahlian. Mencari pekerjaan di kota tidaklah mudah seperti yang dibayangkan, apalagi tanpa keahlian. Walaupun pekerjaan tidak didapat, akan tetapi hidup harus tetap berjalan yang pada akhirnya untuk menyambung hidup terpaksa mengemis atau mengamen.

Pengemis di perkotaan semakin lama semakin banyak dengan alasan untuk mencari kebutuhan hidup. Pekerjaan mengemis bisa dilakukan di mana pun, kapan pun tanpa membutuhkan keterampilan khusus, yang diperlukan hanya mengubah penampilan sehingga memunculkan rasa kasihan pada orang lain sehingga orang lain pun ingin memberi saat ia meminta. Para pengemis biasanya di dominasi oleh orang tua (usia lanjut) atau orang tua dengan menyertakan anak-anak, orang yang cacat secara fisik, ataupun anak-anak dan ada juga orang yang relatif dari sisi fisik mampu bekerja. Sedangkan gelandangan dominan terdiri dari kalangan anak-anak muda, usia produktif, bahkan usia sekolah guna menyambung hidup, gelandangan ini juga meminta belas kasihan orang 
lain dengan mengemis tetapi menggunakan alat musik biasanya yang dikenal dengan istilah pengamen. Uang yang diperoleh sering kali digunakan untuk berfoya-foya bersama teman-teman seperti nongkrong atau kumpul-kumpul.

Kuntari dan Hikmawati dalam kajiannya menyatakan bahwa hal yang menyebabkan pengemis sulit untuk diatasi adalah motivasi hidup masyarakat yang rendah dalam berjuang, cenderung senang dengan hal instan karena dari hasil mengemis mereka mendapatkan penghasilan yang lumayan besar (Kuntari \& Hikmawati, 2017). Akan tetapi, hasil penelitian Setiawan, menyatakan gelandangan dan pengemis yang terdapat di Kota Yogyakarta merupakan masyarakat urban yang tidak dapat beradaptasi dengan kehidupan kota sehingga bertransformasi dalam pekerjaan informal (Setiawan, 2020). Lain halnya dengan Sridiyatmika, menyatakan bahwa praktik mengemis yang terjadi di Yogyakarta sebenarnya telah terjadi karena adanya tradisi Kemis dari kesultanan dan pada saat ini bertransformasi dalam masalah sosial karena faktor ekonomi (Sridiyatmika, 2018). Sementara itu, Fadillah dan Pospos mengidentifikasi faktor penyebab pengemis dan gelandangan di Kota Langsa dapat dilihat dari faktor struktural, yaitu tingkat pendidikan dan bantuan pemerintah sedangkan faktor kultur adalah visi dan misi hidup serta sikap pasrah (Fadillah \& Pospos, 2017)

Melihat berbagai kasus tersebut, persoalan pengemis menjadi tidak sederhana karena disinyalir para pengemis ini diorganisir oleh orang-orang tertentu untuk melakukannya. Orang tersebut berperan menjamin keamanan pengemis dan membagi wilayah kerja, tentu dengan memberikan imbalan padanya. Penyebaran gelandangan dan pengemis biasanya ada di perempatanperempatan jalan, tempat-tempat wisata, pasar, masjid, dan tempat umum lainnya. Oleh karena itu, permasalahan ini bukanlah hal yang biasa, hasil penelitian Anggriana dan Dewi pun menyatakan penyebab kasus itu terjadi juga karena adanya sikap malas dan ingin hidup instan (Anggriana \& Dewi, 2016). Dengan demikian, peran dinas sosial menjadi sangat penting melalui upaya rehabilitasi dan tindakan preventif lainnya sebagainya yang diungkapkan oleh Khairunnisa, dkk dalam kajiannya (Khairunnisa et al., 2020).

Berdasarkan Kitab Undang-Undang Hukum Pidana (KUHP) terdapat aturan tentang tindak pidana mengemis dan gelandangan yaitu tertulis dalam Pasal 504 ayat (1) yang berbunyi "Barang siapa minta-minta (mengemis) di tempat umum dihukum karena minta-minta, diancam dengan kurungan paling lama enam minggu". Kemudian ayat (2) "Minta-minta yang dilakukan Bersamasama oleh tiga orang atau lebih, yang masing-masing umurnya di atas enam belas tahun, diancam dengan kurungan paling lama tiga bulan". Mengenai gelandangan diatur dalam Pasal 505 ayat (1) "Barang siapa bergelandangan tanpa pencarian, diancam, karena melakukan pergelandangan, dengan kurungan paling lama tiga bulan". Ayat (2) "Pergelandangan yang dilakukan oleh tiga orang atau lebih, yang masing-masing umurnya di atas enam belas tahun, diancam dengan kurungan paling lama enam bulan".

Indonesia berprinsip negara hukum. Di satu sisi Undang-Undang Dasar 1945 (UUD 1945) secara eksplisit mencantumkan dalam Pasal 34 ayat (1) tertera "Fakir miskin dan anak-anak terlantar dipelihara oleh negara". Konstitusi mengamanahkan pemerintah untuk mengatasi orang miskin akan tetapi, di sisi lain, dalam KUHP orang yang mengemis apa pun alasannya diancam dimasukkan sebagai tindak pidana. Pasal 27 UUD 1945 dalam ayat (2) menyebutkan bahwa "Tiap-tiap warga negara berhak atas pekerjaan dan penghidupan yang layak bagi kemanusiaan", artinya tersirat amanah hak warga negara berarti kewajiban Negara.

Berdasarkan ambiguitas beleid di atas, muncul beberapa pertanyaan sosiologis yakni antara lain: (1) apakah penyebab orang melakukan tindakan mengemis? jawabannya karena miskin dan untuk menyambung hidup, padahal orang miskin secara jelas dijamin dalam konstitusi sehingga menjadi tanggung jawab negara. (2) Mengapa orang bisa menggelandang atau menjadi gelandangan? secara sosiologis bisa langsung dijawab tidak memiliki mata pencaharian atau pekerjaan, padahal mengingat secara konstitusi telah mengatur dan menjamin bahwa negara berkewajiban untuk menyediakan lapangan pekerjaan sehingga warga negara bisa hidup dengan layak sebagaimana diatur dalam Pasal 27 ayat (2) UUD 1945. Mendapatkan penghidupan yang layak adalah hak warga negara maka sebaliknya bagi negara menjadi kewajiban untuk menyediakan lapangan pekerjaan.

Mengatasi pengemis dan gelandangan menjadi persoalan yang kompleks di setiap daerah perkotaan, pengaturan dalam UU juga ambigu dan tumpang tindih. Pada penelitian ini, penulis ingin 
meneliti tentang penegakan hukum tindakan pengemis dan gelandangan di Daerah Istimewa Yogyakarta. Berdasarkan data dari Dinas Sosial selama tahun 2014 yang telah diberlakukan terdapat 83 orang yang terjaring operasi penegakan dan semua mendapatkan rehabilitasi di balai sosial oleh Dinas Sosial. Hal ini pun juga sesuai dengan kajian terdahulu di Banda Aceh yang menyatakan bahwa peran Dinas Sosial dalam menangani masalah pengemis dan gelandangan agar dapat memiliki penghidupan yang lebih layak tidaklah mudah ada beberapa hambatan sehingga memerlukan upaya dari berbagai pihak (Suryani \& Sufyan, 2018)

Hal lain, juga dinyatakan oleh Prasasi dkk dalam penelitiannya di Semarang bahwa usaha dinas sosial juga membutuhkan payung hukum yang kuat agar dapat menangani kasus tersebut. Program-program pemerintah daerah setempat juga menjadi sangat penting untuk menangani kasus pengemis dan gelandangan tersebut (Prasasi et al., 2016). Senada dengan kajian sebelumnya, Kencana, dkk dalam kajiannya di Kota Palembang juga menunjukkan peran peraturan pemerintah daerah dalam mengatasi permasalahan gelandangan dan pengemis terus diupayakan dalam berbagai program yang dengan harapan dapat mengatasi kasus tersebut (Kencana et a1., 2020). Jahidin dan Syarif dalam kajiannya menguraikan mengenai penerapan sistem Camp Assemsment yang dilakukan oleh Dinas Sosial DIY untuk mengatasi masalah gelandangan dan pengemis dengan berbagai tahaptahap yang terukur. Meskipun demikian, kasus ini pun masih belum dapat teratasi secara maksimal (Jahidin \& Sarif, 2017).

Daerah Istimewa Yogyakarta sebagai daerah pariwisata, maka kenyamanan para wisatawan menjadi hal yang penting untuk mendukung kota wisata. Pekerjaan sebagai gelandangan dan pengemis dilihat dari sisi kemanusiaan dianggap sebagai tindakan yang merendahkan martabat kemanusiaan. Salah satu langkah Pemerintah Daerah Istimewa Yogyakarta untuk mengatasi persoalan gelandangan dan pengemis adalah dengan cara membuat Peraturan Daerah Nomor 01 Tahun 2014 Tentang Penanganan Gelandangan dan Pengemis. Paparan pendahuluan memunculkan persoalan tentang bagaimana penegakan hukum peraturan daerah nomor 01 tahun 2014 di Kota Yogyakarta? Apa kendala-kendala yang ditemukan dalam penegakan perda tersebut?

\section{Metode}

\section{Metode Pendekatan}

Penelitian ini merupakan penelitian normatif yaitu meneliti dengan mengkaji, menganalisis sumber hukum primer, sumber hukum sekunder dan sumber non hukum yaitu menganalisis perundang-undangan terkait, dalam hal ini peraturan daerah, buku-buku literatur, dan dokumen tertulis serta hasil penelitian terdahulu.

Penelitian ini menggunakan tiga (3) metode pendekatan hukum, yaitu:

a. Pendekatan Yuridis, pendekatan dalam memahami hukum dari kaidah normatif hukum atau aturan hukum tersebut beserta penjelasannya.

b. Pendekatan Kebijakan, pendekatan dalam pembuatan keputusan yang berorientasi kepada tujuan yang hendak dicapai.

c. Pendekatan Nilai, memahami keberadaan suatu aturan undang-undang dari sudut pandang nilainilai yang melandasi pembentukan undang-undang tersebut.

\section{Metode Analisis}

Analisis data dengan menggunakan analisis kualitatif yaitu analisis yang menguraikan data penelitian menjadi komponen melalui rangkaian kata-kata dan atau gambar. Pengkajian Penegakan Peraturan Daerah Nomor 01 Tahun 2014 dimulai dari: (1) pengertian Gelandangan dan Pengemis sesuai dengan peraturan daerah, (2) tindakan Pidana apa saja yang diatur dalam peraturan daerah, dan upaya-upaya yang dilakukan oleh penegak hukum dan (3) kendala apa saja yang ditemui dalam melakukan penegakan hukum serta (4) apa solusi yang ditempuh dalam melakukan penegakan hukum. Analisis kualitatif lebih menekankan analisis terhadap kualitas data dari pada kuantitas data 
itu sendiri. Kesimpulan diambil dengan cara deduktif yaitu menyimpulkan dari suatu yang bersifat umum ke dalam hal-hal uang bersifat khusus.

\section{Hasil dan Pembahasan}

\section{Penegakan Hukum}

Pengertian penegakan hukum secara etimologi, penegakan hukum terdiri dari dua kata yaitu penegakan dan hukum. Penegakan memiliki arti sebagai suatu proses, perbuatan, dan cara menegakkan. Sedangkan hukum adalah ide (dalam istilah sosiologi: "meaning") tentang atau yang bertujuan mencipta: keadilan, ketertiban, keamanan, ketenteraman, kepastian, kelestarian komunitas, efisiensi, satu sama lain tergantung dari keadaan atau kasus dimana para pihak berada. Hukum juga bisa dimaknai sebagai kaidah atau peraturan-peraturan tingkah laku dan kebiasaan masyarakat yang memuat atas suruhan dan larangan (Apheldoorn, 1985: 31).

Satjipto Raharjo, mengemukakan bahwa dalam setiap masyarakat harus ada hukum yang mengatur perilaku-perilaku dan tata kehidupan anggota masyarakat. Untuk adanya tata hukum dalam masyarakat diperlukan komponen kegiatan yaitu pembuatan norma-norma hukum, pelaksana normanorma hukum tersebut dan penyelesaian sengketa yang timbul dalam suasana tertib hukum tersebut. Apabila melihat bahwa di kehidupan masyarakat di Indonesia saat ini, maka dapat dilihat bahwa telah banyak peraturan-peraturan yang dikeluarkan untuk menjaga kelangsungan hidup bernegara dan bermasyarakat.

Leon Duguit, memberikan pengertian bahwa hukum adalah aturan tingkah laku para anggota masyarakat, aturan yang daya penggunaannya pada saat tertentu diindahkan oleh suatu masyarakat sebagai jaminan dari kepentingan bersama dan yang jika dilanggar menimbulkan reaksi bersama terhadap orang yang melakukan pelanggaran (Sudarsono,1991: 43). Definisi menurut Leon Duguit, ada hal-hal yang harus digaris bawahi dalam mengartikan hukum yaitu adanya aturan, masyarakat, jaminan kepentingan, dan sanksi atau efek dari hukum.

Ada juga yang mengartikan bahwa hukum itu bertalian dengan manusia dan manusia merupakan satuan yang melakukan tindakan-tindakan untuk memenuhi segala apa yang berharga bagi hidupnya, karena dorongan batin (Sewojo,1951: 58). Keberagaman definisi hukum menunjukan bahwa hukum dapat diterangkan sesuai dengan perspektif mana ia memandang atau dari sisi mana tergantung dari kondisi sosial yang melingkupinya.

Dalam hal ini, penegakan hukum diartikan sebagai aplikasi hukum terhadap suatu kejadian atau peristiwa. Penegakan hukum dapat pula diartikan sebagai hal yang menegakkan atau mempertahankan hukum oleh para penegak hukum apabila telah terjadi pelanggaran hukum akan atau mungkin dilanggar. Definisi ini mengartikan ada beberapa faktor ditegakkan hukum yaitu ada faktor aturan yang mengatur sesuatu, kemudian penegak hukum dan peristiwa hukum atau akan ada pelanggaran hukum atau kemungkinan adanya pelanggaran baru terjadi penegakkan hukum (Rahardjo, 1979: 102).

Penegakan hukum dalam perspektif sosiologis adalah bahwa penegakan hukum itu bukan merupakan suatu tindakan yang pasti, menerapkan hukum terhadap suatu kejadian yang dapat diibaratkan menarik garis lurus antara dua titik tetapi penegakan hukum itu mengandung pilihan dan kemungkinan, oleh karena dihadapkan kepada suatu kenyataan yang kompleks (Rahardjo, 2002: 173).

Dalam perspektif lain, Soerjono Soekanto berpendapat bahwa secara konsepsional penegakan hukum adalah kegiatan menyerasikan hubungan nilai-nilai yang terjabarkan dalam kaidahkaidah/pandangan-pandangan nilai yang mantap dan mengejawantah dalam sikap tindak sebagai rangkaian penjabaran nilai tahap akhir untuk menciptakan (sebagai "social engineering"), memelihara dan mempertahankan (sebagai "social control") kedamaian pergaulan hidup (Soekanto, 2012: 1). Definisi tersebut dapat diartikan bahwa penegakan hukum merupakan kesatuan nilai-nilai, sistem norma dan sistem aturan-aturan perilaku dan perilaku itu sendiri. 
Ada yang merumuskan bahwa penegakan hukum sebagai suatu usaha melaksanakan hukum sebagaimana mestinya mengawasi pelaksanaannya agar tidak terjadi pelanggaran, memulihkan hukum yang dilanggar itu supaya tegak kembali (Muhammad, 1997: 115).

Lain lagi menurut Satjipto Raharjo, merumuskan definisi penegakan hukum sebagai berikut: "Penegakan hukum adalah suatu proses untuk mewujudkan keinginan-keinginan hukum menjadi kenyataan, adapun disebut keinginan hukum di sini tidak lain adalah nilai-nilai badan pembentuk undang-undang yang dirumuskan dalam peraturan-peraturan hukum proses penegakan hukum ikut menentukan bangunan penegakan hukum itu dijalankan.

Penegakan hukum dalam arti luas mencakup kegiatan untuk melaksanakan dan mengimplementasikan hukum serta melakukan tindakan hukum terhadap setiap pelanggaran atau penyimpangan hukum yang dilakukan oleh subjek hukum, baik melalui prosedur peradilan ataupun melalui prosedur arbitrase dan mekanisme penyelesaian sengketa lainnya (alternative desputes or conflicts resolution). Sedangkan dalam arti sempit, penegakan hukum itu menyangkut kegiatan penindakan terhadap setiap pelanggaran atau penyimpangan terhadap peraturan perundang-undangan, khususnya yang lebih sempit lagi melalui proses peradilan pidana yang melibatkan aparat Kejaksaan, Kepolisian, Advokat atau Pengacara, dan badan-badan peradilan (Asshiddiqie, 2006)

Selain itu, menurut Satjipto Rahardjo penegakan hukum dapat dibedakan menjadi dua yakni: (1) penegakan hukum semata-mata dilihat dari peraturan sebagai kelanjutan logis atau proses logis diciptakannya peraturan hukum. (2) penegakan hukum sebagai keterlibatan manusia dalam proses bekerjanya hukum (Rahardjo, 2002: 174:1). Dijk dalam Abdurahhman, dalam Sabian Utsman mengatakan bahwa hukum harus dipahami dengan latar belakang masyarakat yang seluas-luasnya, semua peran ganda memperlihatkan sifat khotis (murni) fungsi dari sistem mereduksi kompleksitas tersebut. Dengan cara tersebut kehidupan menjadi tertata dan kepastian dalam masyarakat dapat diciptakan (Utsman, 2008: 10).

Penegakan hukum tidak bisa dilepaskan dari pemaknaan akan hukum itu sendiri maka penegakan hukum memiliki pengertian di atas akan dipengaruhi sedikit banyak oleh pemahaman masyarakat tentang aturan hukum positif yang berlaku. Menurut Prof. Barda Nawawi, penegakan hukum pidana ada tiga yaitu : (1) penegakan hukum pidana formulatif yaitu penegakan hukum pidana pada taraf bagaimana memformulasikan hukum pidana dalam peraturan hukum. (2) penegakan hukum yudikatif proses Sistem Peradilan Pidana (SPP) "Penegakan hukum in concreto". (3) penegakan hukum eksekutif, penegakan hukum tidak hanya diartikan dalam pengertian yang sempit yaitu penegakan melalui proses peradilan akan tetapi penegakan hukum di sini diartikan dalam pengertian yang luas (Barda Nawawi, 2001: 21) yaitu seluruh norma dan atau tatanan kehidupan bermasyarakat dalam hal ini berfokus pada penanganan gelandangan dan pengemis.

Sudikno Mertokusumo lebih lanjut menjelaskan, melalui penegakan hukum inilah hukum itu menjadi kenyataan. Hukum harus dilaksanakan dan ditegakkan. Fiat justitia et pereat mundus "Meskipun dunia ini akan runtuh hukum harus ditegakkan" (Mertokusumo, 2008: 160).

\section{Pengaturan Penalisasi Tindakan Mengemis dan Gelandangan}

Perbuatan mengemis dan gelandangan di dalam KUHP diatur dalam Bab I Pasal 504 ayat (1) Barang siapa minta-minta (mengemis) di tempat umum dihukum karena meminta-minta, dengan kurungan selama-lamanya enam minggu; (2) minta-minta yang dilakukan Bersama-sama oleh tiga orang atau lebih, yang masing-masing umurnya lebih dari 16 tahun, dihukum kurungan selamalamanya tiga bulan. Pengaturan ini memiliki maksud melarang kepada orang miskin meminta belas kasihan di tempat umum, misalnya di pasar, stasiun, terminal, perempatan-perempatan jalan dan sebagainya, karena perbuatan itu dianggap dapat mengganggu kepentingan orang lain yang sedang bepergian, atau sedang melakukan aktivitas. Perbuatan meminta-minta di tempat umum juga dilihat kurang pantas dan amat memalukan karena merendahkan diri sendiri tidak menghargai harkat dan martabat kemanusiaan.

Perbuatan meminta-minta merupakan pekerjaan yang tidak terhormat, Allah SWT sangat membenci/melarang pekerjaan yang meminta-minta. Sebagaimana hadist Muslim yang artinya bahwa "Telah menceritakan kepada kami Abu Bakar bin Abu Syaibah telah menceritakan kepada 
kami Abdul A'la bin Abdul A'la dari Ma'mar dari Abdullah bin Muslim saudaranya Zuhri, dari Hamzah bin Abdullah dari bapaknya bahwa Nabi shallallahu 'alaihi wasallam bersabda: "Tidaklah salah seorang dari kalian yang terus meminta-minta, kecuali kelak di hari kiamat ia akan menemui Allah sementara di wajahnya tidak ada sepotong daging pun." Dan telah menceritakan kepadaku Amru An Naqid telah menceritakan kepadaku Isma'il bin Ibrahim telah mengabarkan kepada kami Ma'mar dari saudaranya Az Zuhri dengan isnad ini, namun ia tidak menyebutkan muz'ah (sepotong).(HR. Muslim). Hal ini dimaksudkan sebagai ancaman keras bagi pekerjaan memintaminta. Nabi Muhammad SAW ingin menjaga kehormatan seorang muslim, membiasakan untuk bersikap menahan diri dari ketergantungan kepada orang lain. Sebaliknya selalu bergantung pada diri sendiri dan menjauhi diri dari meminta-minta kepada manusia. (An-Nawawi, 2010: 390). Hal tersebut juga diungkapkan Almujaddedi dan Zainuddin dalam kajiannya mengenai hukum Islam terhadap pengemis dan gelandangan, bahwa Allah mengharamkan perbuatan yang meminta-minta sehingga permasalahan ini memang merupakan bagian yang perlu diupayakan teratasi di berbagai daerah di Indonesia (Almujaddedi \& Zainuddin, 2019)

Meminta-minta (mengemis) dapat dilakukan dengan meminta-minta secara lisan, tertulis atau memakai gerak-gerik. Bisa juga dengan cara menjual lagu-lagu dengan jalan menyanyi, biola, kecrek, kendang, angklung, seruling dan jenis lainnya. Permainannya dapat dilakukan dari rumah ke rumah, atau dari toko ke toko yang biasa dilakukan di kota besar, hal ini dapat termasuk dalam pengertian mengemis.

Gelandangan juga diatur dalam KUHP pada Pasal 505 ayat (1) barang siapa dengan tidak mempunyai pencaharian mengembara ke mana-mana dihukum karena pelancong dengan kurungan selama-lamanya tiga bulan, ayat (2) Pelancongan yang dilakukan Bersama-sama oleh tiga orang atau lebih yang masing-masing umurnya lebih dari 16 tahun, dihukum kurungan selama-lamanya enam bulan. R. Susilo menerangkan pelancongan yang dimaksud adalah mengembara, gelandangan, atau bertualang, artinya berkelana ke sana-kemari berpindah-pindah dari satu tempat ke tempat yang lain. Ini dapat dihukum apabila petualang itu tidak mempunyai mata pencaharian. Biasanya dilakukan dengan meminta-minta ke sana kemari.

Gelandangan dan pengemis dalam Peraturan Daerah Nomor 01 Tahun 2014 Tentang Penanganan Gelandang dan Pengemis mendefinisikan dalam Pasal 1 ketentuan umum sebagai berikut ayat (2) Gelandangan adalah orang yang hidup dalam keadaan tidak sesuai dengan norma kehidupan yang layak dalam masyarakat setempat serta tidak mempunyai tempat tinggal dan pekerjaan tetap di wilayah tertentu dan hidup mengembara di tempat umum. Ayat (3) Pergelandangan adalah suatu tindakan pengembaraan yang dilakukan oleh individu dan/atau sekelompok orang yang tidak memiliki tempat tinggal dan pekerjaan tetap di wilayah tertentu, serta hidupnya berpindahpindah di tempat umum. Ayat (4) Gelandangan psikotik adalah gelandangan yang mempunyai gangguan jiwa. Ayat (5) Pengemis adalah orang-orang yang mendapatkan penghasilan dengan meminta-minta di muka umum dengan berbagai cara dan alasan untuk mengharapkan belas kasihan dari orang lain. Pengertian tentang tindakan mengemis dan menggelandang antara KUHP dan Peraturan Daerah Nomor 01 Tahun 2014 memiliki kesamaan. Tindakan meminta-minta di tempat umum untuk mendapatkan belas kasihan dari orang lain dan perbuatan penggelandangan tanpa memiliki mata pencaharian sehingga mereka makan dari belas kasihan orang lain.

Pengenaan sanksi pidana pada dua perbuatan tersebut menandakan bahwa kedua perbuatan tersebut merupakan perbuatan tercela, hal ini dilandasi bahwa perbuatan tersebut, merendahkan martabat kemanusiaan dan mengganggu ketertiban umum. Pelabelan kriminalisasi terhadap perbuatan mengemis dan gelandangan perlu dicermati ulang, sehingga penegak hukum tidak kebingungan saat menegakkan hukum.

Beberapa penelitian telah dilakukan berkaitan dengan implementasi Peraturan Daerah Nomor 01 Tahun 2014 tentang Penanganan Gelandangan dan Pengemis di Unit Pelaksana Teknis (UPT) Panti Karya telah melaksanakan Peraturan Daerah Nomor 01 Tahun 2014 dengan upaya preventif, koersif, rehabilitatif, dan reintegrasi sosial. Penanganan selanjutnya terkendali oleh pembiayaan dari APBD sehingga belum sepenuhnya bisa dilaksanakan.

Data dari Dinas Sosial tahun 2011 tentang gelandangan dan pengemis tahun 2008-2012 ditunjukkan pada Tabel 1. 
Tabel 1

Data Gelandangan dan Pengemis DIY

\begin{tabular}{|c|c|c|c|c|c|}
\hline \multirow{2}{*}{\begin{tabular}{l}
\multicolumn{1}{c}{ Data } \\
gelandangan \\
pengemis DIY dan
\end{tabular}} & 2008 & 2009 & 2010 & 2011 & 2012 \\
\hline & $\begin{array}{ll}\text { jiwa } & 800\end{array}$ & jiwa 1.248 & $\begin{array}{ll}\text { jiwa } & 515\end{array}$ & 451 & 247 \\
\hline
\end{tabular}

Nitha Chitrasari (skripsi dengan judul "Kinerja Dinas Sosial Kota Cilegon dalam Penanganan Gelandangan dan Pengemis Kota Cilegon, Universtas Agung Tirtayasa 2012) dalam skripsi, Faisal mengemukakan bahwa penanganan Gelandangan dan Pengemis (Gepeng) di kota Cilegon masih sangat minim, kinerja suatu organisasi bila dilihat dari produktivitas, kualitas layanan, responsivitas, responsibilitas, dan akuntabilitas. Umumnya kegiatan meng-Gepeng ini dilakukan oleh ibu-ibu yang disertai dengan anak-anaknya. Mereka umumnya relatif muda dan termasuk dalam tenaga kerja yang produktif.

Perlakuan terhadap tindakan orang miskin yang mengemis bila melihat hukum Islam, pada surat Al-Maun sangat kontradiktif dengan perlakukan UU terhadap orang yang mengemis. Surat AlMaun memberikan pengertian bahwa "Jangankan menghukum, menghardik saja berdosa". Namun perbuatan tersebut tepat untuk dihukum apabila meng-Gepeng dibarengi dengan tindak pidana yang lain atau meminta dengan paksaan, mengganggu ketertiban umum serta dengan kekerasan.

Agama Islam sebagai agama mayoritas masyarakat Indonesia sehingga menjadi bagian dari hukum yang hidup di masyarakat. Sebab agama bukan hanya diyakini dalam hati akan tetapi harus dilaksanakan dalam kehidupan sehari-hari. Saat memperlakukan orang lain dalam agama islam terdapat keyakinan bahwa akan terkena hukuman dan labelling pendusta agama yaitu orang yang menghardik anak yatim dan tidak mengasihi orang miskin. Orang miskin menjadi bagian dari kehidupan keberagamaan.

Sehubungan dengan hal tersebut, pemerintah daerah diharapkan memiliki program atau upaya yang efektif dalam menangani kasus gelandangan dan pengemis. Yoel, dkk dalam hasil penelitiannya terhadap kasus pengemis dan gelandangan di Surabaya yaitu adanya interior tempat edukasi yang dirancang sebagai upaya menangani kasus tersebut. Hal tersebut diupayakan agar pengemis dan gelandangan yang telah mendapatkan edukasi dapat memiliki pola hidup yang berbeda dan berupaya untuk penghidupan yang lebih baik (P et al., 2017).

\section{Ketentuan Pidana pada Peraturan Daerah Nomor 01 Tahun 2014}

Peraturan Daerah Nomor 01 Tahun 2014 Tentang Penanganan Gelandangan dan Pengemis mendefinisikan dalam Pasal 1 ayat (5) pengemis adalah orang yang mendapat penghasilan dengan meminta-minta di muka umum dengan pelbagai cara dan alasan untuk mengharapkan belas kasihan dari orang lain. Sedangkan pengemisan adalah tindakan yang dilakukan oleh individu dan/atau sekelompok orang dengan pelbagai alasan, cara dan alat untuk mengharapkan belas kasihan dari orang lain sebagaimana dalam Pasal 1 ayat (6).

Pengemisan sebagaimana dimaksud dalam Pasal 1 ayat (6) memiliki kriteria sebagaimana diatur dalam Bab II Peraturan Daerah Nomor 01 Tahun 2014 Pasal 6 antara lain: (a) mata pencariannya tergantung pada belas kasihan orang lain, agak terpaksa/takut (b) berpakaian kumuh, compang-camping dan tidak sewajarnya, (c) berada di tempat-tempat umum, ramai/strategis: dan (d) memperalat sesama untuk merangsang belas kasihan orang lain.

Gelandangan sebagaimana dimaksud oleh Pasal 1 ayat (2) adalah orang yang hidup dalam keadaan tidak sesuai dengan norma kehidupan yang layak dalam masyarakat setempat serta tidak mempunyai tempat tinggal dan pekerjaan tetap di wilayah tertentu dan hidup mengembara di tempat umum. Pergelandangan adalah suatu tindakan pengembaraan yang dilakukan oleh individu dan/atau 
sekelompok orang yang tidak memiliki tempat tinggal dan pekerjaan tetap di wilayah tertentu, serta hidupnya berpindah-pindah di tempat umum.

Kriteria Gelandangan sebagaimana diatur dalam Bab II Pasal 5 adalah orang-orang yag memiliki kriteria: (a) tanpa Kartu Tanda Penduduk (KTP) (b) tanpa tempat tinggal yang pasti/tetap (c) tanpa penghasilan yang tetap; dan (d) tanpa rencana hari depan anak-anaknya maupun dirinya.

Pengemis menurut Zairin Harahap dapat diklasifikasikan menjadi tiga, yang pertama mengemis untuk sesuap nasi agar dapat bertahan hidup, kedua mengemis sebagai pekerjaan sementara sebelum mendapat pekerjaan yang tetap dan ketiga mengemis sebagai profesi untuk mendapatkan uang yang banyak tanpa perlu bekerja keras. Pengemis dari sisi modus juga dapat diklasifikasikan menjadi lima model yaitu: (a) mengemis dengan membawa anak, (b) mengemis dengan terlebih dahulu memainkan alat musiknya sendiri maupun berkelompok, (c) mengemis tanpa alat musik, tetapi langsung meminta-minta, (d) mengemis dengan membawa kotak kardus yang bertuliskan meminta sumbangan, (e) mengemis dengan membagikan amplop kosong agar nantinya diisi uang oleh para pemberi.

Ada persoalan lagi yang harus terjawab adalah apakah pengamen termasuk pengemis, sebab pada Peraturan Daerah Nomor 01 Tahun 2014 Pasal 1 ayat (6) tentang pengemisan termasuk meminta-minta dengan pelbagai cara dan alasan serta menggunakan alat. Ditegaskan lagi pada Pasal 9 ayat (2) poin (d) disebutkan dengan frasa meminta-minta dengan menggunakan alat walaupun mungkin pada kriteria pengemis tentang pakaian yang lusuh dan compang-camping tidak termasuk, akan tetapi meminta-minta mengharapkan belas kasih adalah termasuk. Persoalan lagi bahwa apakah pengamen termasuk dalam pengemis atau masuk pada pekerjaan seni jalanan atau seniman jalanan. Di Daerah Istimewa Yogyakarta pengamen dengan pelbagai macam kreativitasnya termasuk salah satu kekhasan Yogyakarta baik dilakukan perseorangan maupun kelompok dan dilakukan di tempat umum.

Peraturan Daerah Nomor 01 Tahun 2014 mengatur tentang tindakan yang diberikan sanksi pidana artinya bahwa perbuatan tersebut masuk sebagai delik pidana diatur dalam Pasal 21 yaitu : setiap orang dilarang: (a) melakukan pergelandangan dan/atau pengemisan baik perseorangan atau berkelompok dengan alasan, cara dan alat apapun untuk menimbulkan belas kasihan orang lain (b) memperalat orang lain dengan mendatangkan seseorang/beberapa orang baik dari dalam daerah ataupun dari luar daerah untuk maksud melakukan pergelandangan dan/atau pengemisan; dan (c) mengajak, membujuk, membantu, menyuruh, memaksa dan mengkoordinir orang lain secara perorangan atau berkelompok sehingga menyebabkan terjadinya pergelandangan dan/atau pengemisan.

Persoalan dilema tersebut akhirnya terjawab bahwa tindakan pengamen yang dilarang adalah tindakan pergelandangan/pengemisan. Dengan kata lain, yang termasuk Tindakan tersebut adalah pengamen yang melakukan usahanya dengan cara berkeliling dan pendapatan yang dihasilkannya bersumber dari harapan belas kasihan dari orang yang dituju. Ciri-ciri pengamen gelandangan adalah berpindah-pindah sampai mendapatkan sedikit uang dalam tempo yang cepat, berharap balas kasihan dari orang lain, tidak mempunyai kreativitas melainkan hanya memaksimalkan apa yang dimiliki, serta bukan niat untuk menghibur. Pengamen jenis ini juga berperilaku premanisme. Premanisme adalah kegiatan sekelompok orang yang mendapatkan penghasilannya terutama dari pemerasan sekelompok masyarakat lain yang bersifat seperti orang yang suka memeras dan melakukan kejahatan. (Nugroho, Sularto, dan Wisaksono, 2017).

Sedangkan pengamen yang tidak termasuk pergelandangan/pengemisan adalah para pengamen yang berusaha untuk menunjukkan profesionalitasnya serta menjauhi segala kategori gelandangan. (Putra, 2019). Menurut Kartono (2018) pengamen yang menjauhi unsur meminta-minta memiliki ciri-ciri dari pengamen ini adalah sudah memiliki grup, memiliki izin usaha, tidak berpindah-pindah dalam tempo yang cepat (biasanya 6-12 jam), mempunyai tempat usaha sendiri sesuai dengan izin pemerintah, serta tidak mengharapkan balas kasihan dari orang lain. Pengamen seperti ini sudah berusaha untuk terorganisir dan membentuk nama grup musisi mereka. Pendapatan mereka murni atas upah atas nyanyian mereka bukan karena balas kasihan. Pengamen ini juga memiliki kreativitas tersendiri sehingga memungkinkan adanya persaingan usaha dengan grup lain. (Putra, 2019 dan Masduki \& Widyatama, 2019) 
Tindakan yang dilarang bukan hanya tindakan pengemisan dan gelandangan akan tetapi tindakan memberikan uang/barang kepada gelandangan dan pengemis juga diatur sebagai tindak pidana sebagaimana yang diatur dalam Pasal 22 yang berbunyi: (1) setiap orang/lembaga/badan hukum dilarang memberi uang dan/atau barang dalam bentuk apapun kepada gelandangan dan pengemis di tempat umum. (2) Pemberian uang dan/atau barang sebagaimana dimaksud dalam ayat (1) dapat disalurkan melalui lembaga/badan sosial sesuai peraturan perundang-undangan.

Ketentuan pidana yang dapat dikenakan diatur dalam Pasal 24 Bab VIII yang berbunyi: (1) setiap orang yang melanggar ketentuan pergelandangan dan/atau pengemisan sebagaimana dimaksud dalam pasal 21 huruf (a), diancam dengan hukuman pidana kurungan paling lama 6 (enam) minggu dan/atau denda paling banyak Rp. 10.000.000,00 (sepuluh juta rupiah), (2) setiap orang yang melanggar ketentuan pergelandangan dan pengemisan secara berkelompok sebagaimana dimaksud dalam Pasal 21 huruf (a) diancam dengan hukuman pidana kurungan paling lama (tiga) bulan dan/atau denda paling banyak Rp. 20.000.000,00 (dua puluh juta rupiah), (3) setiap orang yang melanggar ketentuan memperalat orang lain sebagaimana dimaksud dalam pasal 21 huruf (b) diancam dengan hukuman pidana kurungan paling lama 1 (satu) tahun dan/atau dnda paling banyak Rp. 50.000.000,00 (lima puluh juta rupiah) sebagaimana diatur dalam Kitab Undang-Undang Hukum Pidana, (4) setiap orang yang melanggar ketentuan mengajak, membujuk, membantu, menyuruh, memaksa dan mengkordinir orang lain secara perorangan atau berkelompok sebagaimana dimaksud dalam pasal 21 huruf (c) diancam dengan hukuman pidana kurungan paling lama 6 (enam) bulan dan/atau denda paling banyak Rp. 40.000.000,00 (empat puluh juta rupiah), (5) Setiap orang yang melanggar ketentuan memberi uang dan/atau barang dalam bentuk apa pun kepada gelandangan dan pengemis di tempat umum sebagaimana dimaksud dalam Pasal 22 diancam dengan hukuman pidana kurungan paling lama 10 (sepuluh) hari dan/atau denda paling banyak Rp. 1.000.000,00 (satu juta rupiah).

Peraturan Daerah Nomor 01 Tahun 2014 mengelompokkan ada empat (4) tindakan yang dapat dipidana yaitu (1) setiap orang yang melakukan pengemisan/penggelandangan baik perorangan maupun kelompok, (2) orang yang memperalat orang lain untuk melakukan pengemisan/penggelandangan. (3) orang yang mengajak, membujuk, membantu, menyuruh, memaksa dan mengkordinir orang lain untuk melakukan pengemisan/penggelandangan dan (4) orang/lembaga atau badan hukum yang memberi uang dan/atau barang dalam bentuk apapun kepada pengemis/gelandangan di tempat umum. Peraturan daerah ini juga menyasar subyek baik person (orang) maupun rechtpersoon (badan hukum/korporasi).

\section{Penegakan Hukum Tindak Pidana Pengemisan}

Penegakan hukum sebuah implementasi aturan hukum terhadap suatu kejadian atau peristiwa. Penegakan hukum dapat pula diartikan sebagai hal yang menegakkan atau mempertahankan hukum oleh para penegak hukum apabila telah terjadi pelanggaran hukum akan atau mungkin dilanggar. Definisi ini mengartikan ada beberapa faktor ditegakkan hukum yaitu ada faktor aturan yang mengatur sesuatu, kemudian penegak hukum dan peristiwa hukum atau akan ada pelanggaran hukum atau kemungkinan adanya pelanggaran dahulu baru terjadi penegakan hukum.

Penegakan hukum tidak bisa dilepaskan dari pemaknaan akan hukum itu sendiri, maka penegakan hukum dipengaruhi sedikit banyak oleh pemahaman masyarakat tentang aturan hukum positif yang berlaku, budaya hukum, fasilitas yang tersedia, keyakinan masyarakat dan struktur hukum.

Obyek penegakan hukum dalam Peraturan Daerah Nomor 01 Tahun 2014 adalah tindakan pergelandangan dan pengemisan yang dilakukan di tempat umum baik dilakukan individu maupun kelompok berdasarkan kriteria pada delik pidana yang diatur dalam Pasal 21.

Pemerintahan kota Yogyakarta telah mengupayakan pelbagai upaya dalam penanggulangan Gepeng di antaranya menggunakan upaya preventif dengan cara memberikan pelatihan keterampilan kerja terutama kepada Gepeng yang masih produktif, di antaranya: (1) membuka lapangan kerja agar gelandangan bisa bekerja sehingga tidak menggelandang lagi, memperbanyak peluang kerja pada bidang pariwisata dan juga pengembangan ekonomi kreatif (2) peningkatan pendidikan, melalui rumah singgah para gelandangan dan pengemis yang masih usia sekolah kemudian disekolahkan atas 
bantuan dinas sosial (3) konsultasi sosial terhadap gelandangan dan pengemis dengan cara membantu memecahkan persoalan penyebab melakukan kegiatan pengemisan dan penggelandangan.

Selain upaya preventif dilakukan pula upaya koersif yaitu dengan cara Satuan Polisi Pamong Praja (Satpol PP) secara rutin melakukan penertiban tempat tinggal para Gepeng. Biasanya mereka tinggal di depan toko, di tempat peribadatan, bawah jembatan, dan di pinggir jalan/tempat umum, trotoar dan lainnya. Razia Gepeng juga dilakukan secara rutin kemudian dilakukan pembinaan. Aparat Sapol PP dengan dibantu oleh polisi dan dinas sosial melakukan penjangkauan kemudian dilakukan pembinaan di rumah pembinaan sosial agar mereka tidak kembali untuk melakukan aktivitas meng-Gepeng. Selain itu, juga melakukan penjangkauan bersama dinas sosial dan polisi. Selama ini belum pernah ada yang dipidana hanya sampai dilakukan pembinaan oleh para pekerja sosial di bawah koordinasi dinas sosial. Penggunaan hukum pidana dalam menanggulangi tindak pidana Gepeng baru dilakukan setelah ada rekomendasi dari dinas sosial.

Upaya terakhir yang dilakukan pemerintahan Kota Yogyakarta adalah melakukan rehabilitasi dan reintegrasi sosial yaitu upaya pemberian motivasi dan diagnosa psiko sosial kemudian dilanjutan dengan mengembalikan para Gepeng yang terjaring dalam kehidupan normal di dalam masyarakat.

\section{Kendala-Kendala Penegakan Hukum Tindak Pidana Pengemisan}

Pertama, belum ada Peraturan yang mengatur tentang teknis pelaksanaan peraturan daerah sehingga aparat pelaksana secara operasional masih terkendala tentang pembagian kewenangan antara Satpol PP ditingkat provinsi dengan Satpol PP ditingkat kabupaten/kota.

Kedua, penafsiran terhadap peraturan daerah masih belum harmonis/sama, sehingga muncul keraguan di lapangan saat akan melakukan penindakan. Sehingga berimplikasi pada di satu sisi, masuk kategori mencari nafkah dengan cara meminta belas kasihan orang lain dengan menggunakan alat musik di tempat umum. Jelasnya pengamen yang menggunakan peralatan musik dalam jumlah cukup banyak di perempatan-perempatan jalan biasa dikenal orkes jalanan dengan menggunakan angklung, kendang, kecrek, ansambel, saron dari bambu, drum dan lainnya. Di sisi lain, kehadiran komunitas orkes jalanan ini menjadi bagian dari khas Kota Yogyakarta sebagai manifestasi dari ekspresi seni serta suatu pekerjaan yang profesional sebab penampilan yang disajikan grup musik adalah penampilan yang menghibur penikmat kuliner khas Jogja. Akan tetapi di akhir pertunjukan mereka mengedarkan kotak sebagai manifestasi apresiasi penikmat dengan memberikan sejumlah uang. Hal ini masih menjadi pertanyaan, implikasi dari belum adannya tafsir pengamen secara eksplisit/tegas dalam regulasi Peraturan Daerah Nomor 01 Tahun 2014, apakah tindakan tersebut masuk dalam kategori pengemis atau bukan.

Ketiga, penindakan terhadap kaum dermawan pada Pasal 22 Peraturan Daerah Nomor 01 Tahun 2014 tentang Gepeng, dalam Pasal tersebut tercantum "Setiap orang atau lembaga atau badan hukum dilarang memberi uang dan atau barang dalam bentuk apa pun kepada gelandangan dan pengemis di tempat umum". Ancaman pidana pada tindakan ini ada pada Pasal 24 yang bunyinya "Setiap orang yang melanggar ketentuan memberi uang dan atau barang dalam bentuk apa pun kepada gelandangan dan pengemis di tempat umum sebagaimana dimaksud dalam Pasal 22 diancam dengan hukuman pidana kurungan paling lama 10 hari dan atau denda paling banyak satu juta rupiah". Kontradiktif pada pemahaman tentang dermawan atau orang yang memberikan hartanya, bersedekah kepada orang yang membutuhkan dalam ajaran Islam kegiatan dermawan adalah kegiatan yang baik dan tidak pantas untuk dipidanakan, malah dianjurkan. Hal ini, membuat keraguan pada Satpol PP untuk melakukan penindakan sehingga sampai saat ini belum ada penindakan terhadap orang yang memberi sesuatu kepada pengemis di tempat umum.

Keempat, sering kali ditemukan bahwa Gepeng bukanlah warga Jogja, melainkan berasal dari daerah lain. Maka untuk menanggulanginya perlu adanya sinergisitas/kerjasama lintas daerah bahkan wilayah. Sehingga apabila nanti kembali ditemukan kasus serupa, tidak akan terkendala, sudah dapat dilakukan penindakan.

\section{Gelandangan dan Pengemis dalam Pandangan Islam}

Islam memandang tentang tindakan mengemis sangat tergantung dari latar belakang /alasan orang tersebut melakukan tindakan pengemisan. Apabila mengemis didasari karena keterpaksaan 
disebabkan oleh kemiskinan. Mengemis untuk memenuhi kebutuhan dasar, untuk makan dan minum karena dari sisi fisik sudah tidak mampu bekerja maka mengemis kategori ini memiliki hak yang harus dihormati dan tidak boleh dihina apalagi dipenjarakan. Bahkan, mereka memilik hak diantara harta orang yang kaya seperti dalam Qur'an surat Ad-Dzariyat ayat (19) yang artinya: "Dan di dalam harta mereka itu terdapat hak bagi orang miskin yang meminta, dan orang miskin yang tidak mendapatkan bagian". Dilanjutkan Qur'an surat Ad-Duha ayat (10) yang artinya "Dan terhadap orang yang meminta-minta maka hendaknya kamu tidak menghardiknya". Bahkan, dalam Islam mengungkit pemberian pun tidak diperbolehkan karena akan menghilangkan pahala sedekah. Islam sangat menghargai orang miskin, orang yang tidak punya dan mengemis karena terdesak oleh kebutuhan.

Kembali ditegaskan oleh Nabi Muhammad SAW yang memberikan kelonggaran mengemis bagi seseorang dalam keadaan yang bersifat atau karena suatu kebutuhan yang mendesak. Maka, bagi siapa yang terpaksa meminta-minta karena dorongan kebutuhan yang mendesak dan meminta bantuan dengan cara meminta maka tiada dosa baginya untuk meminta-minta. Lebih jelasnya, kebutuhan mendesak yang dimaksud adalah: (1) orang yang menanggung suatu tanggungan, sebelum dia hidup mampu dibolehkan baginya untuk meminta kepada orang lain hingga ia dapat menyelesaikan tanggungannya itu, jika tanggungannya telah selesai kemudian menahan diri dan tidak meminta lagi kepada orang lain. (2) orang yang ditimpa musibah yang menyebabkan kehilangan harta, dibolehkan baginya untuk meminta kepada orang lain hingga ia mendapatkan penompang hidupnya. (3) orang yang ditimpa bencana, yang menyebabkan kehilangan seluruh harta benda, seperti bencana tsunami, gunung meletus, banjir, gempa bumi dll. (An-Nawawi, 2010: 398-399)

Mengemis dengan alasan bukan karena kebutuhan akan tetapi bagian dari pekerjaannya atau profesinya maka orang tersebut dianggap telah melakukan maksiat. Bahkan, Nabi Muhammad SAW mengancam dengan ancaman yang cukup keras seperti dalam Hadist yang diriwayatkan oleh Muslim "Siapa saja yang meminta harta orang untuk memperbanyak hartanya, (bukan karena kebutuhan), maka sesungguhnya ia tak lain kecuali meminta bara api (neraka), maka hendaknya ia sedikitkan, atau perbanyak". Dalam Hadist lain, Rasulullah bersabda "Tidaklah seseorang di antara kalian selalu meminta-minta, kecuali dia akan menghadap Allah SWT sementara wajahnya tak terbungkus daging" (HR Muslim). Pengemis kategori ini maka sangat layak untuk dikriminalisasi karena sudah merendahkan harkat dan martabat kemanusiaan.

Gelandangan berbeda dengan pengemis walaupun gelandangan juga sering mengemis. Gelandangan orang yang kebutuhan dasarnya tidak terpenuhi baik rumah, maupun makanan apalagi sandang. Pengemis kadang ia sudah punya tempat tinggal. Berbeda dengan gelandangan yang seharusnya menjadi tugas negara atau negara harus hadir memenuhi janjinya (amanat konstitusi) bahwa orang yang terlantar dipelihara oleh negara artinya negara harus berupaya untuk mengentaskan para gelandangan sehingga terpenuhi kebutuhan dasarnya. Jika negara sudah memenuhi kebutuhan dasarnya tapi ia enggan untuk berubah maka pantas pula untuk dikriminalisasi. Sering kali Gepeng disebabkan faktor kemalasan bekerja.

Islam mengajarkan umatnya untuk bekerja keras dan memuliakan orang yang mampu memberi sebagian harta yang ia peroleh kepada orang yang membutuhkan. Memberi dalam Islam merupakan anjuran, bahkan dalam surat Al-Maun disebutkan orang yang kaya dan ia tak mau memberikan pada orang yang miskin, membutuhkan maka ia di-labelling sebagai pendusta agama. Islam juga melarang keras bahkan memberikan ancaman bagi orang yang meminta-minta bukan karena kebutuhan bahkan ancaman lebih keras dari kriminalisasi yang diatur Peraturan Daerah Nomor 01 Tahun 2014.

\section{Simpulan}

Penegakan hukum Peraturan Daerah Nomor 01 tahun 2014 Tentang Penanganan Gelandangan dan Pengemis di kota Yogyakarta sudah mulai dijalankan tetapi belum optimal masih terkendala beberapa hal. Upaya-upaya telah dilakukan oleh Pemerintah Kota Yogyakarta untuk menangani persoalan Gepeng. Pelbagai upaya telah dilakukan oleh pemerintah kota baik yang sifatnya preventif, koersif sampai pada upaya rehabilitasi yang diikuti dengan upaya reintegrasi sosial. Sekalipun peraturan daerah yang mengatur tentang Gepeng memberikan peluang untuk dilakukan 
upaya dengan menggunakan hukum pidana akan tetapi sampai saat ini belum ada yang ditangani menggunakan sanksi pidana. Hal ini, dikarenakan setelah upaya koersif dilakukan dari dinas sosial selaku dinas yang menangani persoalan sosial belum pernah merekomendasikan untuk diselesaikan dengan upaya pidana. Ini juga dilatarbelakangi oleh tidak harmonisnya/ belum jelasnya regulasi terkait tafsir apa saja yang termasuk kategori tindakan penggelandangan dan pengemisan. Persoalan penanganan Gepeng tidak hanya disebabkan oleh satu faktor akan tetapi oleh banyak faktor. Kriminalisasi Gepeng serta orang yang memberi bantuan kepada mereka, oleh peraturan daerah masih menyisakan problem tersendiri. Faktor budaya masyarakat, keyakinan masyarakat, fasilitas, struktur penegak hukum, dan political will dari pemerintah sangat berpengaruh dalam penegakan hukum. Islam memandang pengemis dan gelandang memiliki value yang berbeda, sehingga harus bisa dipisahkan satu sama lain sesuai dengan akar persoalan. Mengemis karena terdesak kebutuhan akibat kemiskinan maka diperbolehkan tapi hanya untuk memenuhi kebutuhan saja. Bahkan, orang yang berpunya sangat keras dilarang untuk menghina apalagi sampai mengriminalisasikan. Islam sangat keras ancamannya bagi orang yang mengemis karena pekerjaan atau profesinya, sanksi dunia dan akhirat akan menanti. Islam juga memandang negara harus hadir untuk mengatasi gelandangan karena memang ia belum bisa memenuhi kebutuhan dasarnya.

\section{Referensi}

Almujaddedi, M. S., \& Zainuddin. (2019). Profesi Pengamen dalam Perspektif Hukum Ekonomi Syariah. Hukum Islam, XIX(2), 100-116.

Anggriana, T. M., \& Dewi, N. K. (2016). Identifikasi Permasalahan Gelandangan Dan Pengemis Di Upt Rehabilitasi Sosial Gelandangan Dan Pengemis. INQUIRY Jurnal Ilmiah Psikologi, 7(1), 3140.

Fadillah, A., \& Pospos, F. W. (2017). Fenomena Pengemis Di Kota Langsa (Kajian Terhadap FaktorFaktor Yang Menyebabkan Seseorang Menjadi Pengemis). Jii, 2(2), 97-112.

Jahidin, A., \& Sarif. (2017). Model Sistem Rujukan Gelandangan dan Pengemis di Camp Assesment Dinas Sosial DIY. EMPATI: Jurnal Ilmu Kesejahteraan Sosial, 6(1), 39-54. https://doi.org/10.15408/empati.v6i1.9781

Kencana, U., Yuswalina, \& Triyandhy, E. (2020). Efektivitas Peraturan Daerah yang Berkesejahteraan Sosial di Kota Palembang: Studi Kasus Anak Jalanan, Gelandangan dan Pengemis di Masa Pandemi Covid-19. Sumber Cahaya, 27(2), 70-97. https://doi.org/10.28946/sc.v27i2.1039

Khairunnisa, T., Purnomo, E. P., \& Salsabila, L. (2020). Smart Urban Service Upaya Rehabilitasi dan Preventif Pengemis dan Gelandangandi Kota Yogyakarta. Journal Moderat, 6(1), 29-42.

Kuntari, S., \& Hikmawati, E. (2017). Melacak Akar Permasalahan Gelandangan Pengemis (Gepeng). Media Informasi Penelitian Kesejahteraan Sosial, 41(No. 1), 11-26.

P, Y. S., Sari, S. M., Wondo, D., Studi, P., Interior, D., Petra, U. K., \& Siwalankerto, J. (2017). Perancangan Interior Tempat Edukasi Gelandangan dan Pengemis di Surabaya. Jurnal Intra, 5(2), 313-321.

Prasasi, C. A., ALW, L. T., \& Herawati, R. (2016). Pelaksanaan Peraturan Daerah Kota Semarang Nomor 5 Tahun 2014 Tentang Anak Jalanan, Gelandangan Dan Pengemis. Diponegoro Law Review, 5(2), 1-15.

Setiawan, H. (2020). Fenomena Gelandangan Pengemis sebagai Dampak Disparitas Pembangunan Kawasan Urban dan Rural di Daerah Istimewa Yogyakarta. Jurnal MODERAT, 6(2), 361-375.

Sridiyatmika, G. (2018). Keberadaan Komunitas Pengemis di Kota Yogyakarta Dalam Kajian IPS Mengenai Budaya Kemiskinan Akibat Proses Reproduksi Sosial. Jurnal Sosialita, 10(1), 33-52.

Suryani, I., \& Sufyan. (2018). Kewenangan Dinas Sosial Kota Banda Aceh dalam Menanggulangi Gelandangan dan Pengemis di Kota Banda Aceh. Jurnal Ilmiah Mahasiswa Biadang Hukum Kenegaraan, 2(November), 833-842. 